\title{
Comparison of methods for germination testing of Cannabis sativa seed
}

\author{
Dušica Jovičić* · Zorica Nikolić · Vladimir Sikora · Gordana Tamindžić · Gordana Petrović · \\ Maja Ignjatov · Dragana Milošević
}

Institute of Field and Vegetable Crops, Maksima Gorkog 30, 21000 Novi Sad, Serbia

\begin{abstract}
Summary: The most critical aspect of plant survival and reproduction is seed germination. Considering the specificity of the Cannabis sativa production, obtaining high-quality hemp seed is not an easy task. Germination testing is often the most reliable way of assessing viability, but the selection of appropriate methods is complex. This study aimed to evaluate the effect of different conditions (i.e. various methods of germination testing) on the successful process of hemp seed germination, achieving maximum germination potential. Our results showed that C. sativa seeds germinated well in different methods, such as between filter papers, top of filter papers and sand, but there were significant differences between the applied methods. This means that the hemp seeds may have different requirements for germination than conditions covered by the Rules recommended methods. Further, the results show that hemp seed may have certain residual dormancy that needs to be investigated in detail.
\end{abstract}

Key words: Cannabis sativa, dormancy, hemp, seed germination testing

\section{Introduction}

Hemp (Cannabis sativa L.) is one of the earliest cultivated plants (Sikora et al., 2011) and today it has multiple applications in industry, primarily in the production of fiber, crushed for oil, food, and feed (Abot et al., 2013). Although neglected during the 1960s, over the past twenty years the areas under this crop have increased significantly (FAO, 2018). Whether it is in the form of raw seed or as a derivative (e.g. cold-pressed seed oil), hemp seeds have become increasingly popular both as food and nutrient supplement. In addition to being rich in unsaturated fatty acids, it is also rich in proteins, namely $100 \mathrm{~g}$ serving of seeds meets up to $63 \%$ of the recommended daily value for protein (USDA, 2016). Due to the presence of THC in the seed, a secondary metabolite used as a narcotic, hemp has been prohibited in many countries in the previous century (Salentijn et al., 2014).

\section{Corresponding author:}

dusica.jovicic@ifvens.ns.ac.rs

Acknowledgement:

This study results from project TR 31025 "Development of new varieties and production technology improvement of oil crops for different purposes" funded by Ministry of Education, Science and Technological Development of the Republic of Serbia.

Cite this article:

Jovičić D., Nikolić Z., Sikora V., Tamindžić G., Petrović G., Ignjatov M., Milošević D. (2019). Comparison of methods for germination testing of Cannabis sativa seed. Ratar: Pourt., 56 (3), 71-75.
The most critical aspect of plant survival and reproduction is seed germination. Considering the specificity of the production of this plant species, obtaining high-quality hemp seed is not an easy task. Although the method for germination testing of hemp seed is indicated in the rules (ISTA, AOSA, Rule of testing seed of agricultural plants (Official Gazette SFRY $47 / 87)$ ), it has been observed that different methods can give different results. The optimum conditions for germination should enable the germination of all viable seeds using the simplest possible method, but germination testing process can be specific in the case of hemp seeds, due to high amount of oil in hemp seed. Moreover, studying seed germination patterns is important for successful cultivation of plants, as well as for understanding the establishment of plant species and their response to abiotic stresses (Hu et al., 2018).

The present study was conducted in order to evaluate the effect of different conditions (i.e. different methods of germination testing) on the successful process of hemp seed germination and the increasing percentage of germination

\section{Material and Methods}

Five samples of industrial hemp seeds (Sample 1, Sample 2, Sample 3, Sample 4, and Sample 5) were used in this experiment. Seeds of cultivar Helena were produced in 2018 at the same locations at the Institute of Field and Vegetable Crops, Novi Sad. Initial seed water content varied between 9.0 and $10.0 \%$. The moisture 
content was determined by the oven method at $130-133^{\circ} \mathrm{C}$ for one hour, with two sub-samples of $4.5 \pm 0.5 \mathrm{~g}$ of seeds for each sample (ISTA, 2018). Uniform seed water content is necessary to standardize evaluations and obtain consistent results.

In order to examine the difference between several methods for germination testing on hemp seed, six different methods were applied to determine the maximum germination potential of seed samples. Filter paper (5 methods) and sand (1 method) were used as a germination medium. For each method, four replicates of 100 seeds were sown on moist filter paper in Petri dishes and placed at $20-30^{\circ} \mathrm{C}$ for 7 days. After 3 days, germination energy was determined by counting only seedlings which essential structures are well developed. After 7 days the total number of typical seedlings, atypical seedlings, and nongerminated seeds were counted. ISTA (2018) states the following definition: "atypical seedlings do not show potential for further development into satisfactory plants when grown in good quality soil and under favorable conditions of moisture, temperature and light". Seeds which did not germinate by the end of the test period were classified as non-germinated seeds.

All methods are listed below:

$\mathrm{BP}_{\mathrm{H} 2 \mathrm{O}}$ - between papers moistened with distilled water (method recommended by ISTA);

$\mathrm{BP}_{\mathrm{KNO} 3}$ - between papers moistened with $\mathrm{KNO}_{3}$ solution;

$\mathrm{BP}_{\mathrm{GA} 3}$ - between papers moistened with gibberellic acid;

$\mathrm{BP}_{\mathrm{Pch}}$ - between papers moistened with distilled water, pre-chilled 3 days at $5-10^{\circ} \mathrm{C}$;

$\mathrm{S}_{\mathrm{H} 20}$ - sand moistened with distilled water;

$\mathrm{TP}_{\mathrm{H} 20}$ - top on paper moisten with distilled water

(Method recommended by ISTA).

All these methods are prescribed by ISTA, but only $\mathrm{BP}_{\mathrm{H} 2 \mathrm{O}}$ and $\mathrm{TP}_{\mathrm{H} 20}$ are recommended for the hemp germination test.

Tetrazolium test was carried out on three replicates of 100 pure seeds drawn at random from either pure seed fraction. The seed was soaked in water at $20^{\circ} \mathrm{C}$ for 18 hours, after which the pericarp was removed in order to expose embryo. Seed prepared in such way was stained in $1.0 \% \mathrm{TZ}$ solution at $30^{\circ} \mathrm{C}$ for 18 hours. After that, distinction of viable and non-viable seeds was conducted according to evaluation criteria of ISTA Rules (2018) Statistical analysis. In order to primarily examine the difference between the tested methods within of a single sample, the one-way analysis of variance and Duncan's multiple range test were applied $(P \leq 0.05)$. Those statistical methods were conducted using the software Statistica 10, while Fisher's Least Significant Difference (LSD) was calculated by software GenStat Release 9.1

\section{Results and Discussion}

Considering that seed germination is an extremely complex process in which many metabolic activities occur, the impact of environmental conditions on imbibition and emergence is significant.

The results show that the energy of germination in all samples, except for sample 4, and in all methods, was greater, or statistically, not much different from the $\mathrm{BP}_{\mathrm{H} 2 \mathrm{O}}$ method (Table 1). For sample 4 in all methods, as well as for sample 5 in the method $\mathrm{S}_{\mathrm{H} 2 \mathrm{O}}$, this was not the case. Although the energy of seed germination is a flexible expansive parameter, its importance is reflected as the first indicator of seed viability, quality, and germination speed, which is undoubtedly significant when it comes to seed field performance.

Significantly higher germination in Sample 1 and Sample 5 at $\mathrm{BP}_{\mathrm{KNO} 3}$ and $\mathrm{BP}_{\mathrm{Pch}}$, as well as at $\mathrm{BP}_{\mathrm{GA} 3}$ in the Sample 2, compared to the recommended methods (Table 2), indicates the possibility of some type of dormancy in the hemp seed, although dormancy should have been eradicated at domesticated seed by selection (Small et al., 2003). On the other hand, external nitrogenous compounds, in this experiment $\mathrm{KNO}_{3}$, are effective substances that help plant growth and promote the vitality and germination of seed (Gniazdowska et al., 2010). They may also be the cause of increased germination in these treatments. In Sample 3, the highest germination was in the $\mathrm{S}_{\mathrm{H} 20}$ method, while for the lowest germination there was no correctness in terms of the method used. In addition, $\mathrm{S}_{\mathrm{H} 2 \mathrm{O}}$ method shows the best result at the low-quality seed sample (Sample 2 - 64.50\%) and quality-good sample (Sample $3-83.00 \%$ and Sample $4-76.75 \%$ ). Such results are somewhat expected, because sand, as a medium for germination, is most similar to the

Table 1. Germination energy of different samples of hemp seeds using different method for germination testing

\begin{tabular}{lccccc}
\hline Energy $(\%)$ & Sample 1 & Sample 2 & Sample 3 & Sample 4 & Sample 5 \\
\hline BP $_{\text {H2O }}$ & $73.50^{\mathrm{cd}}$ & $53.25^{\mathrm{b}}$ & $72.00^{\mathrm{c}}$ & $74.25^{\mathrm{ab}}$ & $50.00^{\mathrm{bc}}$ \\
$\mathrm{BP}_{\text {KNO3 }}$ & $75.25^{\mathrm{bc}}$ & $51.75^{\mathrm{b}}$ & $75.00^{\mathrm{b}}$ & $65.50^{\mathrm{c}}$ & $58.25^{\mathrm{a}}$ \\
$\mathrm{BP}_{\text {GA3 }}$ & $71.75^{\mathrm{d}}$ & $58.25^{\mathrm{ab}}$ & $79.00^{\mathrm{ab}}$ & $71.75^{\mathrm{ab}}$ & $54.50^{\mathrm{ab}}$ \\
BP $_{\text {Pch }}$ & $79.25^{\mathrm{a}}$ & $55.00^{\mathrm{ab}}$ & $78.25^{\mathrm{ab}}$ & $68.50^{\mathrm{bc}}$ & $51.75^{\mathrm{b}}$ \\
$\mathrm{S}_{\text {H20 }}$ & $74.75^{\mathrm{bc}}$ & $62.75^{\mathrm{a}}$ & $83.00^{\mathrm{a}}$ & $75.50^{\mathrm{a}}$ & $42.00^{\mathrm{d}}$ \\
$\mathrm{TP}_{\text {H20 }}$ & $77.25^{\mathrm{a}}$ & $55.25^{\mathrm{ab}}$ & $72.00^{\mathrm{c}}$ & $69.25^{\mathrm{bc}}$ & $45.75^{\mathrm{cd}}$ \\
\hline LSD $_{0.05}$ & 2.90 & 8.50 & 4.87 & 5.98 & 4.77
\end{tabular}

* The differences between different methods and among the same sample are assigned by letters. Means with similar letter are not significantly different, compared by Duncan's multiple range test $(P \leq 0.05)$ 
Table 2. Germination of different samples of hemp seeds using different method for germination testing

\begin{tabular}{lccccc}
\hline Germination (\%) & Sample 1 & Sample 2 & Sample 3 & Sample 4 & Sample 5 \\
\hline BP $_{\text {H2O }}$ & $76.00^{\mathrm{bc}}$ & $54.75 \mathrm{~b}$ & $80.00 \mathrm{a}$ & $76.00 \mathrm{ab}$ & $50.75^{\mathrm{bc}}$ \\
$\mathrm{BP}_{\mathrm{KNO3}}$ & $79.00^{\mathrm{ab}}$ & $52.75 \mathrm{~b}$ & $78.25 \mathrm{ab}$ & $69.75 \mathrm{~b}$ & $59.75^{\mathrm{a}}$ \\
$\mathrm{BP}_{\mathrm{GA3}}$ & $73.00^{\mathrm{c}}$ & $59.25 \mathrm{ab}$ & $80.25 \mathrm{a}$ & $72.50 \mathrm{ab}$ & $55.25^{\mathrm{ab}}$ \\
$\mathrm{BP}_{\text {Pch }}$ & $79.50^{\mathrm{a}}$ & $55.25 \mathrm{~b}$ & $79.25 \mathrm{a}$ & $69.50 \mathrm{~b}$ & $53.25^{\mathrm{b}}$ \\
$\mathrm{S}_{\text {H20 }}$ & $75.75^{\mathrm{bc}}$ & $64.50 \mathrm{a}$ & $83.00 \mathrm{a}$ & $76.75 \mathrm{a}$ & $42.75^{\mathrm{d}}$ \\
$\mathrm{TP}_{\mathrm{H} 20}$ & $77.75^{\mathrm{ab}}$ & $56.00 \mathrm{ab}$ & $73.25 \mathrm{~b}$ & $71.50 \mathrm{ab}$ & $46.50^{\mathrm{cd}}$ \\
\hline LSD $_{0.05}$ & 3.26 & 8.72 & 5.48 & 6.69 & 5.08 \\
\hline
\end{tabular}

* The differences between different methods and among the same sample are assigned by letters. Means with similar letter are not significantly different, compared by Duncan's multiple range test $(P \leq 0.05)$.

soil. Further, examining the effect of storage on the change of the hemp seed by applying a germination test between filter paper at $20^{\circ} \mathrm{C}$, Suriyong et al. (2015) have reported suspicions regarding the confidence on the information obtained from this type of test.

It is well-known that temperature is an important factor for the process of seed germination (Ooi et al. 2012). Previous studies show the importance of higher temperatures for seed germination $(92.4 \%$ at $25 \mathrm{C}$ and $64.3 \%$ at 10C) (Quin et al., 2014), as confirmed by this study, except for Sample 1.

The gibberellic acid is considered as a growthpromoting compound that positively regulates processes such as seed germination (Razem et al. 2006), but this was not confirmed by this study.

Given that the seed of all samples was produced at the same location, under same environmental conditions, the question arises as to why such differences in seed germination occur between samples 1, 3 and 4 compared to samples 2 and 5 . In order to examine the number of vital and non-vital seeds in each sample, a biochemical test for viability (tetrazolium test) was conducted. The results of this test showed a significantly higher percentage of nonvital seeds in the mentioned samples (2 and 5). It is important that a significant proportion of non-vital seeds in these samples were the empty seeds (Table 3). The most probable reason for this can be inadequate seed processing, where empty seeds were not separated. This greatly influenced the overall percentage of germination, and hence the total value of seed lots.

Furthermore, contrary to the germination test, tetrazolium test shows that there is still no dormancy in the tested samples, since the percentage of vital seeds is approximately equal to the total percentage of typical and atypical seedlings obtained in the standard germination test. In other words, when a seed in a

Table 3. Tetrazolium test of five hemp seed samples

\begin{tabular}{lccc}
\hline & $\begin{array}{c}\text { Vital } \\
(\%)\end{array}$ & $\begin{array}{c}\text { Non- } \\
\text { vital (\%) }\end{array}$ & $\begin{array}{c}\text { Empty seed included } \\
\text { in non-vital seed (\%) }\end{array}$ \\
\hline Sample 1 & 85 & 15 & 4 \\
Sample 2 & 70 & 30 & 15 \\
Sample 3 & 89 & 11 & 3 \\
Sample 4 & 83 & 17 & 6 \\
Sample 5 & 66 & 34 & 14 \\
\hline
\end{tabular}

Table 4. Atypical seedlings of different samples of hemp seeds using different method for germination testing

\begin{tabular}{lccccc}
\hline $\begin{array}{l}\text { Atypical } \\
\text { seedlings (\%) }\end{array}$ & Sample 1 & Sample 2 & Sample 3 & Sample 4 & Sample 5 \\
\hline $\mathrm{BP}_{2} \mathrm{O}$ & $1.25^{\mathrm{c}}$ & $3.00^{\mathrm{b}}$ & $1.50^{\mathrm{b}}$ & $2.00^{\mathrm{b}}$ & $3.25^{\mathrm{c}}$ \\
$\mathrm{BP} \mathrm{KNO}_{3}$ & $3.75^{\mathrm{b}}$ & $3.25^{\mathrm{b}}$ & $2.75^{\mathrm{b}}$ & $4.75^{\mathrm{ab}}$ & $5.75^{\mathrm{abc}}$ \\
$\mathrm{BP} \mathrm{GA}_{3}$ & $2.75^{\mathrm{bc}}$ & $3.25^{\mathrm{b}}$ & $3.50^{\mathrm{b}}$ & $2.00^{\mathrm{b}}$ & $6.00^{\mathrm{ab}}$ \\
$\mathrm{BP} \mathrm{Pch}$ & $1.25^{\mathrm{c}}$ & $2.00^{\mathrm{b}}$ & $1.75^{\mathrm{b}}$ & $1.50^{\mathrm{b}}$ & $4.00^{\mathrm{bc}}$ \\
$\mathrm{S} \mathrm{H}_{2} \mathrm{O}$ & $2.25^{\mathrm{bc}}$ & $1.25^{\mathrm{b}}$ & $2.50^{\mathrm{b}}$ & $2.50^{\mathrm{b}}$ & $5.00^{\mathrm{bc}}$ \\
$\mathrm{TP} \mathrm{H}_{2} \mathrm{O}$ & $6.25^{\mathrm{a}}$ & $6.25^{\mathrm{a}}$ & $6.00^{\mathrm{a}}$ & $7.25^{\mathrm{a}}$ & $7.75^{\mathrm{a}}$ \\
\hline $\mathrm{LSD}_{0.05}$ & 1.51 & 2.74 & 2.19 & 3.86 & 2.63 \\
\hline
\end{tabular}

* The differences between different methods and among the same sample are assigned by letters. Means with similar letter are not significantly different, compared by Duncan's multiple range test $(P \leq 0.05)$. 
Table 5. Non-germinated seeds of different samples of hemp seeds using different method for germination testing

\begin{tabular}{lccccc}
\hline $\begin{array}{l}\text { Non-germinated } \\
\text { seeds (\%) }\end{array}$ & Sample 1 & Sample 2 & Sample 3 & Sample 4 & Sample 5 \\
\hline $\mathrm{BP} \mathrm{H}_{2} \mathrm{O}$ & $22.75^{\mathrm{ab}}$ & $42.25^{\mathrm{ab}}$ & $18.50^{\mathrm{ab}}$ & $22.00^{\mathrm{b}}$ & $46.00^{\mathrm{ab}}$ \\
$\mathrm{BP} \mathrm{KNO}_{3}$ & $17.25^{\mathrm{c}}$ & $44.00^{\mathrm{a}}$ & $19.00^{\mathrm{ab}}$ & $25.50^{\mathrm{ab}}$ & $34.50^{\mathrm{d}}$ \\
$\mathrm{BP} \mathrm{GA}_{3}$ & $24.5^{\mathrm{a}}$ & $37.50^{\mathrm{ab}}$ & $16.25^{\mathrm{ab}}$ & $25.50^{\mathrm{ab}}$ & $38.75^{\mathrm{cd}}$ \\
$\mathrm{BP} \mathrm{Pch}^{\mathrm{b}}$ & $19.25^{\mathrm{bc}}$ & $42.75^{\mathrm{ab}}$ & $19.00^{\mathrm{ab}}$ & $29.00^{\mathrm{a}}$ & $42.75^{\mathrm{bc}}$ \\
$\mathrm{S} \mathrm{H}_{2} \mathrm{C}$ & $22.00^{\mathrm{ab}}$ & $34.25^{\mathrm{b}}$ & $14.50^{\mathrm{b}}$ & $20.75^{\mathrm{b}}$ & $46.00^{\mathrm{ab}}$ \\
$\mathrm{TP} \mathrm{H}_{2} \mathrm{C}$ & $16.00^{\mathrm{c}}$ & $37.75^{\mathrm{ab}}$ & $20.50^{\mathrm{a}}$ & $21.25^{\mathrm{b}}$ & $45.75^{\mathrm{ab}}$ \\
\hline $\mathrm{LSD}_{0.05}$ & 3.59 & 9.32 & 4.97 & 5.83 & 6.67 \\
\hline
\end{tabular}

* The differences between different methods and among the same sample are assigned by letters. Means with similar letter are not significantly different, compared by Duncan's multiple range test $(P \leq 0.05)$.

tetrazolium test is evaluated as vital, it means that it has the ability to germinate, but it is questionable if it will develop a typical or atypical seedling.

Although the percentage of germination was not affected, the increased number of atypical seedlings at all Samples at $\mathrm{TP}_{\mathrm{H} 20}$ compared to all $\mathrm{BP}$ methods and $\mathrm{S}_{\mathrm{H} 2 \mathrm{O}}$, was possibly due to the difficulty in maintaining moisture at a constant level. According to Small \& Brookes (2012), the above reason may affect significant variation in germination of the same seed samples when it comes germination test between paper and top of paper method (Table 4).

$\mathrm{BP}_{\mathrm{KNO} 3}$ influenced decrease number of nongerminated seeds at Sample 1 and Sample 5, $\mathrm{TP}_{\mathrm{H} 2 \mathrm{O}}$ at Sample S1 and Sample 4, $\mathrm{S}_{\mathrm{H} 2 \mathrm{O}}$ at Sample 3 and Sample 4, while BPGA3 influenced only Sample 5 (Table 5).

\section{Conclusion}

Our results showed that the seeds of $C$. sativa germinated well in BP, TP and sand methods, but there were significant differences between the applied germination testing methods. The heterogeneity of the samples due to weak seed processing caused the difference in germination between the individual samples.

\section{References}

Abot, C., Bonnafous, F. Touchard, Thibault F., Chocinski-Amault, L. Lemoine, R., De'dalde'champ, F. (2013). Effects of cultural conditions on the hemp (Cannabis sativa) phloem fibres: Biological development and mechanical properties. Journal of Composite Materials, 47(8), 1067-1077. https://doi.org/10.1177/0021998313477669

Gniazdowska, A., Krasuska, U., Czajkowska, K., Bogatek, R. (2010). Nitric oxide, hydrogen cyanide and ethylene are required in the control of germination and undisturbed development of young apple seedlings. Plant Growth Regulation, 61: 75-84.

FAO (2018): Food and agriculture organization of the United Nations. Available at http://www.fao.org/faostat/en/\#data/QC [26 th March 2019]

USDA Full Report (All Nutrients) 12012 (2016). Seeds, hemp seed, hulled. USDA National Nutrient Database for Standard Reference, Release 28.
Hu, H., Liu, H., Liu, F. (2018). Seed germination of hemp (Cannabis sativa L.) cultivars responds differently to the stress of salt type and concentration. Industrial Crops and Products, 123, 254-261. doi: 10.1016/j.indcrop. 2018.06 .089

ISTA (2018): International Rules for Seed testing. Seed Science and Technology. Zurich, Switzerland.

Ooi, M.K.J., Auld, T.D., Denham, A.J. (2012). Projected soil temperature increase and seed dormancy response along an altitudinal gradient: implications for seed bank persistence under climate change. Plant and Soil, 353: 289-303.

Razem, F.A., Baron, K., Hill, R.D. (2006). Turning on gibberellin and abscisic acid signaling. Current Opinion in Plant Biology 9: 454-459.

Quin, C., Wang, F., We, D., Qin, W. (2014). Effect of different temperatures on the germination of fire hemp seeds. Medicinal Plant, 5: 70-72.

Salentijn, E.M.J., Zhang, Q., Amaducci, S., Yang, M., Trindade, L.M. (2014). New developments in fiber hemp (Cannabis sativa L.) breeding. Industrial Crops and Products 68, 32-41. https:// doi.org/10.1016/j.indcrop.2014.08.011

Sikora, V., Berenji, J., Latković, D. (2011). Varijabilnost i međuzavisnost komponenti prinosa konoplje za vlakn (Variability and Interrelation of Yield Components in Fiber Hemp). Ratarstvo i pourtarstvo, 48: 107112.

Small, E., and Brookes, B. (2012). Temperature and moisture content for storage maintenance of germination capacity of seeds of industrial hemp, marijuana, and ditch weed forms of Cannabis sativa. Journal of Natural Fibers, 9: 240-255. doi:10.1080/15440478.2012.737179.

Small E., Pocock T., Cavers P. B. (2003). The biology of Canadian weeds. 119. Cannabis sativa L. Canadian Journal of Plant Science, 83: 217-237. doi: 10.4141/P02-021.

Suriyonga, S., Krittigamasa, N., Pinmaneeb, S., Punyalueb, A., Vearasilp, S. (2015). Influence of storage conditions on change of hemp seed quality. Agriculture and Agricultural Science Procedia 5: 170-176. doi: 10.1016/j.aaspro.2015.08.0262015. 


\title{
Poređenje metoda za ispitivanje klijavosti semena Cannabis sativa
}

\section{Dušica Jovičić · Zorica Nikolić · Vladimir Sikora · Gordana Tamindžić · Gordana Petrović · Maja Ignjatov · Dragana Milošević}

\begin{abstract}
Sažetak: Najkritičnija faza preživljavanja i razmnožavanja biljaka je klijanje semena. S obzirom na specifičnost proizvodnje industrijske konoplje (Cannabis sativa), dobijanje visokokvalitetnog semena konoplje nije jednostavno. Ispitivanje klijavosti je često najpouzdaniji način procene vitalnosti, ali je odabir odgovarajućih metoda složen. Ovo istraživanje je sprovedeno kako bi se procenio efekat različitih uslova tj. različitih metoda testiranja klijavosti, na proces klijanja semena konoplje uz postizanje maksimalnog potencijala za klijanje. Dobijeni rezultati pokazuju da seme C. sativa dobro klija primenom različitih metoda (između filter papira, na filter papiru, pesak), ali postoje značajne razlike između primenjenih metoda. Ovo praktično znači da seme konoplje može imati zahteve za klijavost različite od onih koje su obuhvaćene preporučenim metodama. Takođe, rezultati pokazuju da kod semena konoplje možda postoji neki vid zaostale dormantnosti što je potrebno dodatno istražiti.

Ključne reči: Cannabis sativa, dormantnost, ispitivanje klijavosti semena, konoplja
\end{abstract}

